\title{
ОСОБЛИВОСТІ МОРАЛЬНО-ДУХОВНОГО ВИХОВАННЯ СТУДЕНТСЬКОЇ МОЛОДІ В УМОВАХ ГЛОБАЛІЗАЦІЙНИХ ВИКЛИКІВ ЧАСУ
}

\section{С. І. Ткачов}

д. пед. н., професор, професор кафедри педагогіки та психології

Харківської державної академії фізичної культури

\section{Н. О. Ткачова}

д. пед. н., професор, професор кафедри загальної педагогіки і педагогіки вищої школи Харківського національного педагогічного університету імені Г. С. Сковороди

\section{А. С. Ткачов}

д. пед. н., доцент кафедри початкової і професійної освіти Харківського національного педагогічного університету імені Г. С. Сковороди

Сучасний розвиток українського суспільства характеризується двома важливими тенденціями, що гармонійно доповнюють одна одну. Так, з одного боку, в останні роки відбувається подальше зміцнення української державності й національної ідентичності, посилюється значущість сталих національних традицій та звичаїв, а з іншого спостерігається активна інтеграція України в європейське та світове співтовариство, що передбачає залучення української спільноти до загальнолюдських цінностей, правових та моральних норм демократичної держави.

Слід акцентувати, що наявна суспільно-політична ситуація в Україні зумовила підвищення вимог до результатів морально-духовного виховання студентів вищої школи. Це пов'язано з нагальною потребою формування в майбутніх фахівців позитивного мислення, високої духовної культури, умінь конструктивної взаємодії з людьми, які можуть значною мірою відрізнятися за особистісними переконаннями, культурними традиціями, релігійним віросповіданням тощо, унаслідок чого постає необхідність переосмислення ролі вищої школи у здійсненні морально-духовного виховання студентської молоді.

3 огляду на високу соціальну значущість та багатоаспектність морально-духовного виховання особистості означена проблема сьогодні перебуває в центрі уваги фахівців у різних наукових галузях. Так, філософські засади морально-духовного становлення особистості обгрунтовано в наукових працях В. Баранівського, М. Боришевського, В. Кременя, Ю. Москаленка, Л. Сохань, М. Ценкота ін. Психологічні витоки становлення духовності як унікального соціального феномена розкрито в дослідженнях таких вітчизняних і зарубіжних авторів, як І. Бех, В. Васютинський,О. Киричук, Г. Костюк, Р. Мей, К. Роджерс, М. Фрідман та ін. Окремі педагогічні аспекти здійснення морально-духовного виховання молоді, у тому числі студентів вищої школи, висвітлено в наукових доробках О. Вишневського, І. Зязюна, О. Сухомлинської, К. Чорної, Г. Шевченка, П. Щербаня та ін. Варто відзначити, що вказані науковці зробили вагомий внесок у дослідження проблеми морально-духовного виховання особистості. Проте результати вивчення стану теоретичної та практичної розробленості зазначеної проблеми свідчать про наукову доцільність подальших наукових розвідок. Зокрема, постає актуальна потреба у з'ясуванні особливостей морально-духовного виховання студентської молоді в умовах подальшої глобалізації суспільного життя.

Для уточнення власного розуміння суті морально-духовного виховання вважаємо за доцільне насамперед визначитись із тлумаченням понять «духовність» $\mathrm{i}$ «моральність». Щодо першого з них наведемо трактування М. Боришевського, який під «духовністю» розуміє «утворення у структурі свідомості та самосвідомості особистості, в яких у формі ціннісних орієнтацій віддзеркалюються її найбільш актуальні морально релевантні потреби, інтереси, погляди, ставлення до навколишньої дійсності, до інших людей, до себе самої, що стали суб'єктивно значущими регуляторами активності» [2, с. 10]. У свою чергу, В. Киричок акцентує, що моральність - це «характеристика особливої практичної діяльності людей, що мотивується моральними ідеалами, переконаннями, нормами та принципами» [4, с. 526].

Як з'ясовано, багато сучасних науковців присвячують свої публікації висвітленню різних аспектів духовно-морального виховання молоді. Однак тільки деякі з них визначають власну точу зору щодо визначення суті цього виховання. Так, К. Плівачук стверджує, що духовно-моральне виховання становить цілісний процес засвоєння людиною визначених моральних норм і правил, розвитку соціально значущих мотивів і навичок поведінки [10]. Проте варто зауважити, що в цьому визначенні не відбито духовну складову поняття.

За висновками К. Євсюкової, духовно-моральне виховання спрямоване на забезпечення духовно-морального становлення зростаючої особистості. Цей процес являє собою набуття духовного й морального досвіду, що «вирощується» педагогом під час взаємодії з вихованцем [5, с. 127]. Не заперечуючи правильність висловлених думок авторки, зауважимо, що використані в цьому визначенні поняття («духовно-моральне становлення особистості», «духовний і моральний досвід») вимагають додаткового авторського роз'яснення їхньої суті. 
Більш чітке тлумачення поняття «морально-духовне виховання» наведено в наукових працях Т. Петракової. Як вона пояснює, сутнісними характеристиками людини є духовність і моральність. Перша 3 названих характеристик відображає спрямованість особистості на досягнення обраних нею цілей, вищі («вертикальні») прагнення людини. Друга характеристика відбиває сукупність загальних принципів поведінки людей стосовно один до одного та суспільства загалом. Тому дослідниця сприймає моральність як сферу «горизонтальних» устремлінь індивіда. Ці обидві характеристики людини тісно пов'язані з іï мотиваційною сферою, причому як зовнішньо (моральність), так і внутрішньо (духовність) [8; 9].

На основі наведених міркувань Т. Петракова визначає морально-духовне виховання як відкриту систему виховання, спрямовану на формування емоційно-мотиваційної сфери особистості, що становить системоутворюючий елемент ï внутрішнього світу. Причому цей організований, цілеспрямований процес передбачає здійснення впливу педагога на духовно-моральну сферу особистості і на раціональному, і на емоційно-інтуїтивному рівнях. Важливо також відмітити, що в змісті духовно-морального виховання особистості мають знайти своє відображення всі найбільш суттєві виміри її буття. За висновками Т. Петракової, для успішного здійснення цього процесу педагог у потоці інформації, що пропонується для засвоєння суб'єктам навчання, має виокремлювати й достатньо повно використовувати пї виховний та ціннісний потенціал, а також реалізовувати алгоритми формування в молоді ієрархії соціально значущих ставлень до існуючої дійсності. У свою чергу, це сприятиме самовизначенню особи на основі ऑї самопізнання, самоактуалізації й самореалізації, а також розвитку емоційно-ціннісної сфери як своєрідного ядра особистості [там само].

Зі свого боку Л. Хоружа та В. Киричок наголошують, що в умовах інтенсивного реформування вітчизняної системи освіти існує актуальна потреба в розробці та впровадженні нової концепції духовно-морального виховання, зорієнтованої на розвиток духовності української молоді, забезпечення засвоєння кожною особистістю світоглядних та загальнолюдських цінностей та моральних норм [11, с. 29]. Дослідники також пояснюють, що саме поняття духовності розглядається в науковій літературі з трьох основних позицій: онтології - як розуміння і сприйняття іiі у контексті особистісно-буттєвої і соціально-буттєвої складової; теології - як певна мета, «божественний проект» або «ціль» розвитку особистості в її світському визначенні; аксіології - як розуміння триєдиної ідеї «істина-добро-краса», що забезпечуються розумовим, моральним та естетичним вихованням особистості [11, с. 27].

На основі врахування наведених вище міркувань науковців визначено, що духовність — це інтегративна особистісна якість, що забезпечує спроможність людини до активного самотворення та перетворення навколишнього світу на засадах вищих моральних цінностей. У свою чергу, моральність являє собою якість людини, що проявляється в її прагненні завжди керуватися у своїх словах, діях та поведінці нормами моралі. 3 урахуванням цього зазначимо, що морально-духовне виховання - це цілеспрямований вплив педагога на вихованців з метою формування в них духовності та моральності. Означений процес має ієрархічний характер та стосується всіх аспектів життєдіяльності людини, забезпечуючи формування іiі ставлень до Творця, Батьківщини, себе та інших людей, праці тощо.

Варто взяти до уваги, що морально-духовне виховання людини найбільш інтенсивно відбувається в дошкільному та шкільному віці. Проте важливість здійснення цього процесу у вищій школі теж не можна недооцінювати. Більш того, у розвитку сучасного українського суспільства, коли відбувається руйнування застарілих соціальних цінностей та їх заміна новими ціннісними пріоритетами, проблема духовно-морального виховання студентської молоді перетворюється в одне з головних завдань державної політики в галузі вищої освіти, сприяючи ствердженню іiї високої духовної місії. Від того, якою мірою випускники вищої школи будуть готові взяти на себе відповідальність за подальшу розбудову в Україні демократичного суспільства, збереження та розвиток культурних здобутків, духовності українського народу, залежить не тільки власна доля молодих фахівців, але й майбутнє держави загалом.

Однак, за результатами опитування студентів, значна кількість респондентів віддає перевагу не духовним, а матеріальним цінностям. Так, більше половини студентів визнали, що після закінчення закладу вищої освіти вони збираються під час пошуку місця роботи насамперед керуватися розміром заробітної платні та враховувати можливості власного кар'єрного росту. Причому близько третини випускників взагалі планують виїхати працювати за кордон, хоч вони не виключають можливості свого повернення на батьківщину у випадку, якщо соціально-економічна ситуація в Україні покращиться.

Решта студентів прагне залишитися жити та працювати в Україні. При цьому багато з них вже сьогодні прагнуть брати активну участь у суспільному житті, займатися професійним самовдосконаленням. Однак часто молоді люди юнацького віку через нестачу життєвого досвіду неспроможні правильно оцінити ті чи інші соціальні явища й процеси, дії різних людей. Тому нерідкими $є$ випадки, коли дорослі зрілі люди (наприклад, політики), маніпулюючи свідомістю студентів та зловживаючи їхнім бажанням відстоювати справедливість, переконують молодих людей брати участь у різних сумнівних заходах, у тому числі противоправного характеру.

У світлі викладеного зазначимо, що педагогічно грамотно організоване морально-духовне виховання студентів допоможе їм не тільки уникнути помилок у виборі власної поведінки в тих чи інших проблемних життєвих ситуаціях, а й обрати правильний шлях освоєння світу, відпрацювати стійке гуманне ставлення до себе та інших людей, виробити ціннісні орієнтації, які визначають загальну життєву позицію людини. 
Значущість порушеної проблеми зумовлена також поглибленням процесу глобалізації, яка сьогодні $є$ визначальним фактором подальшого розвитку суспільства та охоплює всі царини його життєдіяльності: культуру, науку, економіку, освіту, політику тощо. Адже в такій ситуації виникає питання, яким чином забезпечити узгодження й оптимальне поєднання в освітньому процесі вищої школи реалізацію національних та загальнолюдських цінностей, що, з одного боку, сприяє збереженню духовної культури, самобутності, менталітету українського народу, а з іншого - забезпечує залучення студентської молоді до загальної культури людства. При цьому варто відзначити, що світ цінностей саме і $є$ «сферою духовної діяльності людини, ії моральної свідомості, її прихильностей — тих оцінок, у яких відбивається міра духовного багатства людини» [2, с. 21].

Як відомо, ЮНЕСКО проголосило XXI століття століттям освіти, визнавши у такий спосіб ії роль як провідного засобу не тільки розв' язання сучасних глобальних соціальних проблем, але й формування нових духовних підвалин людської цивілізації. У такій ситуації цінності відіграють роль певного ії стабілізуючого компонента, своєрідного підгрунтя для пошуку людьми нових парадигм життя [6, с. 141].

Вищевказане підтверджується думкою В. Андрущенка, який вважає, що в умовах глобалізації суспільства процес модернізації вищої освіти має бути спрямований на підвищення ії̈ ефективності й конкурентоспроможності. Автор також наголошує, що освіта повинна забезпечити «збереження минулого, його очищення від деформацій і осучаснення у відповідності зі світовим досвідом» [1, с. 372]. У свою чергу Г. Калінічева зазначає, що процеси глобалізації в галузі освіти сприяють поглибленню іiї інтернаціоналізації, стандартизації, а це активізує модернізацію вітчизняної системи вищої освіти. Воднораз дослідниця підкреслює, що слід запобігати й негативним впливам глобалізації шляхом розробки та реалізації виваженої стратегії подальшого розвитку вищої школи відповідно до національних інтересів та державних потреб України [7, с. 97].

Оскільки саме в юнацькі роки відбувається становлення системи стійких ціннісних орієнтирів людини, що постають як внутрішній стрижень іії особистості, дуже важливо забезпечити інтеріоризацію студентами соціально значущих, гуманістичних цінностей. У світлі цього О. Дубасенюк цілком справедливо наголошує, що соціальна валідність особистості залежить від ступеня засвоєння нею духовно-моральних цінностей, на основі яких формуються її світоглядні настанови [3, с. 81].

Слід зауважити, що певні резерви щодо здійснення культурно-морального виховання студентської молоді можна використати на заняттях практично з усіх навчальних дисциплін. Однак, особливі можливості в цьому плані містять зміст суспільно-гуманітарних i, зокрема, педагогічних дисциплін. Адже одним із провідних завдань їх викладення є забезпечення відпрацювання кожним суб'єктом освітнього процесу власного ціннісного ставлення до подій чи явищ, які пов'язані з навчальним матеріалом.

Представимо власний досвід викладання дисциплін педагогічного циклу, що забезпечує ефективне морально-духовне виховання студентів. Так, у процесі здійснення педагогічної взаємодії значна увага приділяється збагаченню навчального матеріалу духовно-моральними аспектами. Зокрема, студентам пояснюється роль духовності в ії світському та релігійному трактуванні, значення моралі в житті суспільства й кожного його окремого члена, важливість для нього стати духовно завершеною індивідуальністю.

Також стимулюється пізнання майбутніми фахівцями провідних духовно-моральних цінностей, засвоєння основних знань про моральні норми, про особистісний духовний потенціал та важливість його постійного розвитку, про наявність тісного взаємозв'язку між цим процесом та саморозвитком, самовдосконаленням, самореалізацією суб'єкта навчання. Увага студентів також привертається до того факту, що здійснення особистістю морально-духовного самовиховання, з одного боку, дає їй змогу вийти за межі своєї індивідуальної свідомості та досягти рівня трансперсональних переживань, успішно інтеріоризувати основні загальнолюдські й національні цінності шляхом перетворення їх у суспільно значущі індивідуальні ціннісні орієнтації й ідеали, а з іншого боку - через механізм рефлексії забезпечити постійний розвиток та збагачення власного внутрішнього світу, досягнення гармонії з собою та навколишнім світом, розкриття своїх духовно-інтуїтивних потенцій.

Для формування у студентів адекватних теоретичних уявлень про духовність та моральність як складні особистісні феномени на заняттях широко використовуються різноманітні активні й інтерактивні методи та форми роботи (диспути, ділові й рольові ігри, обговорення проблемних ситуацій, тренінги тощо). Вирішенню поставлених педагогічних завдань, пов'язаних із забезпеченням морально-духовного становлення майбутніх фахівців, сприяє також використання на заняттях кращих зразків мистецтва (фрагменти записів класичних музичних творів, народних пісень, віршів і прози відомих українських та зарубіжних авторів, репродукції картин, вироби декоративно-прикладного мистецтва тощо), які дозволяють здійснювати ефективний вплив не тільки на когнітивну, але й на чуттєво-емоційну сферу особистості.

Під час здійснення морально-духовного виховання студенти також залучаються до написання есе та інших творчих робіт-роздумів, виконання самостійних індивідуальних та групових проектів на теми, пов'язані $з$ порушеною проблематикою (наприклад, «Розвиток духовної культури студентської молоді в умовах глобалізованого суспільства», «Духовні цінності як основа відродження української нації» тощо), забезпечення засвоєння молодими людьми основ педагогіки емпауерменту, опанування технологій самодослідження, самооцінювання, самокоригування, гармонізації своєї інтелектуальної й емоційної сфери, оволодіння методиками визначення ціннісних орієнтацій та рівня духовного розвитку особистості тощо. 
Для успішного здійснення морально-духовного виховання студентів аудиторну роботу з ними доповнено відповідною позааудиторною діяльністю майбутніх фахівців. Так, вони беруть участь у різних видах волонтерської діяльності та інших видах суспільно корисної праці (наприклад, в екологічних акціях), організації та проведенні вікторин, вечорів на відповідну тематику, благодійних концертах тощо.

Отже, можна підсумувати, що в умовах глобалізації суспільства морально-духовне виховання студентів набуває особливої значущості, оскільки воно сприяє розкриттю унікальності кожної молодої людини і водночас допомагає послабити негативні наслідки процесів глобалізації.

\section{Література}

1. Андрущенко В. П. Роздуми про освіту: статті, нариси, інтерв’ю. К., 2004. 804 с.

2. Виховання духовності особистості : навч.-метод. посіб. / М. Й. Боришевський, Л. І. Пилипенко, О.І.Пенькова та ін./ за заг. ред. М. Й. Боришевського. Кіровоград, 2013. 104 с.

3. Дубасенюк О. А. Духовно-моральне виховання студентської молоді. Інноваційні підходи до виховання студентської молоді у вищих навчальних закладах : матеріали Міжнар. наук.-практ. конференції (22-23 травня Житомир). Житомир, 2014. С. 78-87.

4. Енциклопедія освіти / голов. ред. В. Г. Кремень. К., 2008. 1040 с.

5. Свсюкова К. І. Духовно-моральне виховання в контексті християнських цінностей // Нова парадигма. 2014. Вип. 19. C. $120-130$.

6. Живага О. В. Вища освіта в процесах глобалізації (філософський аналіз) // Вісник Національного авіаційного університету. Сер. Філософія, культурологія. 2013. №1. С. 141-144.

7. Калінічева Г. Глобалізаційні виклики часу як детермінанта модернізаційних змін у системі вищої освіти України // Вісник Національного університету «Львівська політехніка». 2008. № 25 (607). С. 90-97.

8. Петракова Т. И. Гуманистические ценности образования в процессе духовно-нравственного воспитания подростков : автореф. дис. ... док-ра пед. наук. М., 1999. 56 с.

9. Петракова Т. И. Духовно-нравственное воспитание в условиях общеобразовательной школы: категории, содержание, критерии. URL: http://www.verav.ru/common/mpublic.php?num=18.

10. Пліванчук К. В. Духовно-моральне виховання учнівської молоді як умова ціннісного становлення особистості // Народна освіта. 2016. Вип 1. С. 37-44. URL: https://www.narodnaosvita.kiev.ua/?page_id=3941..

11. Хоружа Л., Киричок В. Духовно-моральне виховання школярів в Україні: досвід та шляхи вдосконалення // Рідна школа. 2013. № 4-5 (квітень-травень). С. 26-32. 